\title{
Oleic acid induces migration through a FFAR1/4, EGFR and AKT-dependent pathway in breast cancer cells
}

\author{
Cleofas Marcial-Medina, Alejandra Ordoñez-Moreno, Christian Gonzalez-Reyes, Pedro Cortes-Reynosa and \\ Eduardo Perez Salazar
}

Departamento de Biologia Celular, Cinvestav-IPN, Mexico City, Mexico

Correspondence should be addressed to E Perez Salazar: jperez@cell.cinvestav.mx

\begin{abstract}
Free fatty acids (FFAs) are an energy source, and induce activation of signal transduction pathways that mediate several biological processes. In breast cancer cells, oleic acid (OA) induces proliferation, matrix metalloproteinase-9 (MMP-9) secretion, migration and invasion. However, the signal transduction pathways that mediate migration and invasion induced by OA in breast cancer cells have not been studied in detail. We demonstrate here that FFAR1 and FFAR4 mediate migration induced by OA in MDA-MB-231 and MCF-7 breast cancer cells. Moreover, OA induces migration, invasion, AKT1 and AKT2 activation, 12-LOX secretion and an increase of NFKB-DNA binding activity in breast cancer cells. Cell migration requires FFAR1, FFAR4, EGFR, AKT and PI3K activity, whereas invasion is mediated though a PI3K/Akt-dependent pathway. Furthermore, OA promotes relocalization of paxillin to focal contacts and it requires PI3K and EGFR activity, whereas NFKB-DNA binding activity requires PI3K and AKT activity.
\end{abstract}

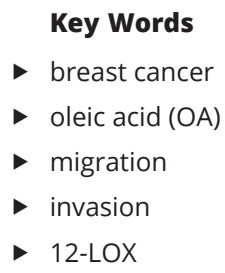

Endocrine Connections (2019) 8, 252-265

\section{Introduction}

Epidemiological studies strongly suggest an association between a higher intake of dietary fat and obesity with an increased risk of developing breast cancer. Moreover, obesity is characterized for an elevation of circulating free fatty acids (FFAs) $(1,2,3,4)$. FFAs are an energy source, and induce activation of signal transduction pathways in breast cancer cells $(5,6,7,8)$. Particularly, oleic acid (OA) induces proliferation, migration and invasion of breast cancer cells $(5,6,8,9,10)$.

Free fatty acid receptor 1 (FFAR1) and FFAR4 are G protein-coupled receptors activated by medium- to longchain fatty acids, such as OA; but they are not activated by short chain FFAs $(11,12)$. FFAR1 is expressed in pancreatic $\beta$-cells and enhances insulin secretion mediated by glucose; whereas FFAR4 is expressed in adipose tissue, macrophages and taste buds and is involved in antiinflammatory response, taste perception and insulin signaling $(13,14,15,16)$. Moreover, FFAR1 and FFAR4 are expressed in MDA-MB-231 and MCF-7 breast cancer cells and mammary non-tumorigenic epithelial cells MCF10A $(9,11,17)$.

The PI3K/AKT/mTOR pathway has been involved in growth, proliferation, survival, metabolism and motility (18). In breast cancer, mutations in the PI3K/AKT pathway are frequently found, and approximately $60 \%$ of tumors have mutations that hyperactive this pathway (19).The family of PI3K lipid kinases generates phosphoinositol lipids that act as second messengers in a number of signaling pathways, including the activation of PDK1 and AKT. The AKT family of serinethreonine kinases consists of three members, namely AKT1, AKT2 and AKT3. The AKT maximum activation requires phosphorylation at threonine (Thr)-308, Thr-309 and Thr-305, and the phosphorylation at serine (Ser)-473, 
Ser-474 and Ser-472 in AKT1, AKT2 and AKT3, respectively $(20,21)$. Particularly, PI3K catalyzes the synthesis of the membrane phospholipid PI $(3,4,5)$, P3 from PI $(3,4)$ P2, which recruit AKT to the plasma membrane and then AKT is activated by its phosphorylation. Activation of AKT promotes its translocation to several subcellular locations, and phosphorylation of targets $(22,23)$.

Arachidonic acid (AA) is an essential fatty acid, which is obtained from dietary sources, and can be derived from linoleic acid. In mammalian cells, AA is esterified into membrane phospholipids and is released mainly by the action of cytosolic phospholipase A2 $\alpha$ (cPLA2 $\alpha$ ). However, AA is also released by other enzymes including PLC and PLD $(24,25)$. Free AA is enzymatically metabolized by three major pathways, namely lipoxygenases (LOXs), cyclooxygenases (COXs) and cytochrome P450 epoxygenases. The LOX pathway generates hydroeicosatetraenoic acids (HETEs), which are the precursors of leukotrienes (LKs), lipoxins (LOs) and hepoxillins (HOs) (26). The COX pathway is mediated by two members, COX-1 and COX-2, which produce prostaglandins (PGs), prostacyclin D2 (PGD2), prostacyclin E2 (PGE2), prostacyclin F2 $\alpha$ (PGF2 $\alpha$ ), prostacyclin I2 (PGI2) and thromboxane A2 (TXA2) (27). In general, AA metabolites (eicosanoids) mediate a variety of cell processes including chemotaxis, inflammation, angiogenesis and apoptosis (28). In MDA-MB-231 breast cancer cells, OA induces FAK activation and migration through a PLC- and LOXs-dependent pathway (8).

In the present study, we studied the signal transduction pathways that mediate migration and invasion induced by $\mathrm{OA}$ in breast cancer cells.

\section{Materials and methods}

\section{Materials}

OA sodium salt and A6730 were from Sigma. AG1478 was from Calbiochem. LY294002, Akt2 siRNAs, antibodies (Abs) against Akt1 (5C10), Akt2 (F-7), and FAK (C-20) were from Santa Cruz Biotechnology. Paxillin $\mathrm{Ab}$ was from Invitrogen. FFAR4 Ab was from OriGene (Rockville, MD, USA). Phosphospecific Ab to Thr-308/Thr-309 of Akt1/Akt2 (anti-p-Akt-Thr) (244F9), and Ser-473/Ser-474 of Akt1/Akt2 (anti-p-Akt-Ser) (9271S) were from Cell Signaling. Phosphospecific Ab to tyrosine (Tyr)-397 of FAK (anti-p-FAK) was from Invitrogen. Actin monoclonal $\mathrm{Ab}$ was kindly provided by $\mathrm{PhD}$ Manuel Hernandez (Cinvestav-IPN). DC260126 and AH7614 were from Tocris
(Minneapolis, MN, USA). Basement membrane matrix (BD Matrigel) was from BD Biosciences (Bedford, MA, USA). $\left(\gamma^{-32} \mathrm{P}\right)$ ATP was from Perkin-Elmer.

\section{Cell culture}

The human MDA-MB-231 and MCF-7 breast cancer cell lines were cultured in Dulbecco's Modified Eagle's Medium (DMEM) supplemented with $3.7 \mathrm{~g} / \mathrm{L}$ sodium bicarbonate, 5\% fetal bovine serum (FBS) and antibiotics in a humidified atmosphere containing 5\% $\mathrm{CO}_{2}$ and $95 \%$ air at $37^{\circ} \mathrm{C}$. For experimental purposes, cultures were serum-starved for $24 \mathrm{~h}$ before treatment.

\section{Preparation of OA solution}

OA solution was prepared with bovine serum albumin (BSA) as described previously $(6,29)$. Briefly, OA bound to BSA (BSA-OA) was prepared by stirring OA sodium salt at $37^{\circ} \mathrm{C}$ with $5 \%$ fatty acid-free BSA. Solution was adjusted to $\mathrm{pH} 7.4$ and filtered through $0.22 \mu \mathrm{m}$ filter and the fatty acid concentration was measured using a fatty acid assay kit (Bio Vision). When BSA-OA was added to serum-free medium, final concentration of BSA was adjusted to $0.005 \%$.

\section{Cell stimulation}

Confluent cultures were washed twice with DMEM without FBS, equilibrated in the same medium at $37^{\circ} \mathrm{C}$ for $30 \mathrm{~min}$, and treated with inhibitors and/or BSA-OA. The stimulation was terminated by aspirating the medium and cells were solubilized with $0.5 \mathrm{~mL}$ of icecold radioimmunoprecipitation assay (RIPA) buffer containing $50 \mathrm{mM}$ HEPES $\mathrm{pH} 7.4,150 \mathrm{mM} \mathrm{NaCl}, 1 \mathrm{mM}$ EGTA, $1 \mathrm{mM}$ sodium orthovanadate, $100 \mathrm{mM} \mathrm{NaF}, 10 \mathrm{mM}$ sodium pyrophosphate, $10 \%$ glycerol, $1 \%$ Triton X-100, $1 \%$ sodium deoxycholate, $1.5 \mathrm{mM} \mathrm{MgCl}_{2}, 0.1 \%$ SDS and $1 \mathrm{mM}$ PMSF. Lysates were clarified by centrifugation at $13,539 \boldsymbol{g}$ for $10 \mathrm{~min}$ at $4^{\circ} \mathrm{C}$. Supernatants were transferred to fresh tubes and the protein level of each sample was determined by the micro Bradford protein assay (Bio-Rad).

\section{Western blotting}

Equal amounts of protein were separated by SDS-PAGE using $10 \%$ separating gels and transferred to nitrocellulose membranes. Next, membranes were blocked using 5\% non-fat dried milk in phosphate buffered saline (PBS)

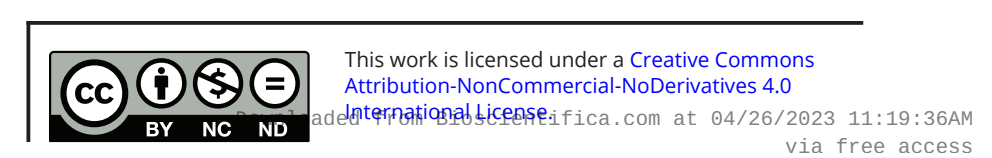


pH 7.2/0.1\% Tween 20 (wash buffer), and incubated overnight at $4^{\circ} \mathrm{C}$ with primary $\mathrm{Ab}$. The membranes were washed three times with wash buffer and incubated with secondary $\mathrm{Ab}$ (horseradish peroxidase-conjugated Abs to rabbit) (1:5000) for $2 \mathrm{~h}$ at $22^{\circ} \mathrm{C}$. After washing, immunoreactive bands were visualized using ECL detection reagent. Autoradiograms were scanned and the labeled bands were quantified using the ImageJ software (https://imagej.nih.gov/ij/).

\section{Immunoprecipitation}

Lysates were clarified by centrifugation at $13,539 \boldsymbol{g}$ for 10 min. Supernatants were transferred to fresh tubes, and proteins were immunoprecipitated overnight at $4^{\circ} \mathrm{C}$ with protein A-agarose linked to a specific $\mathrm{Ab}$ against the target protein. Immunoprecipitates were washed three times with RIPA buffer.

\section{Scratch-wound assay}

Cells were grown to confluence in $35 \mathrm{~mm}$ culture dishes, starved for $24 \mathrm{~h}$ in DMEM and treated for $2 \mathrm{~h}$ with $12 \mu \mathrm{M}$ mitomycin $\mathrm{C}$ to inhibit proliferation. Next, cultures were scratch-wounded using a sterile $200 \mu \mathrm{L}$ pipette tip, washed twice with DMEM and re-fed with DMEM without or with inhibitors and/or BSA-OA. Progress of cell migration into the wound was photographed at $48 \mathrm{~h}$ using an inverted microscope coupled to camera. Each experiment was repeated three times.

\section{Invasion assay}

Invasion assays were performed by the modified Boyden chamber method in 24-well plates containing 12 cellculture inserts with $8 \mu \mathrm{m}$ pore size (Costar, Corning, Inc). An amount of $50 \mu \mathrm{L}$ BD Matrigel was added into culture inserts and kept overnight at $37^{\circ} \mathrm{C}$ to form a semisolid matrix. Cells were plated at $1 \times 10^{5}$ cells per insert in serum-free DMEM on the top chamber. The lower chamber contained $600 \mu \mathrm{L}$ DMEM without or with BSA-OA. Chambers were incubated for $48 \mathrm{~h}$ at $37^{\circ} \mathrm{C}$ in a $5 \% \mathrm{CO}_{2}$ atmosphere, and then cells and Matrigel on the upper surface of membrane were removed with cotton swabs, and cells on the lower surface of membrane were washed and fixed with methanol for $5 \mathrm{~min}$. Number of invaded cells was estimated by staining with $0.1 \%$ crystal violet in PBS. Dye was eluted with $300 \mu \mathrm{L} 10 \%$ acetic acid, and absorbance at $600 \mathrm{~nm}$ was measured. Background value was obtained from wells without cells.

\section{Determination of 12(S)-HETE}

MDA-MB-231 cells were treated with $100 \mu \mathrm{M}$ OA or $15 \mu \mathrm{M}$ AA for $30 \mathrm{~min}$, and supernatants were collected. The concentration of 12(S)-HETE was determined by using the 12(S)-HETE ELISA kit (Enzo Life Sciences, Farmingdale, NY, USA), according to the manufacturer's guidelines.

\section{RNA interference}

AKT2 expression was silenced in breast cancer cells by using the Silencer siRNA kit from Santa Cruz Biotechnology, according the manufacturer's guidelines. One control of scramble siRNAs was included according to the manufacturer's guidelines.

\section{Silencing of FFAR4 with shRNA}

Lentiviral shRNA vectors from Santa Cruz Biotechnology targeting human FFAR4 were utilized for generation of stable knockdown in MDA-MB-231 cells, according the manufacturer's guidelines. Transfected cells were selected by their resistance to puromycin $(5 \mu \mathrm{g} / \mathrm{mL})$.

\section{Immunofluorescence confocal microscopy}

Cells grown on coverslips were stimulated with $\mathrm{OA}$ for various times. After stimulation, cells were fixed with $4 \%$ paraformaldehyde in PBS for $20 \mathrm{~min}$, permeabilized with $0.1 \%$ Triton X-100 in PBS for $20 \mathrm{~min}$, and blocked for $1 \mathrm{~h}$ with 3\% BSA. Cells were stained with TRITC-conjugated phalloidin to reveal F-actin and with anti-paxillin Ab for $12 \mathrm{~h}$ to reveal focal adhesions, followed by incubation with FITC-labeled anti-mouse secondary $\mathrm{Ab}$ for $2 \mathrm{~h}$ at room temperature. Cells were viewed using a Leica confocal microscope (Model TCS SP2; Leica Microsystems). Serial optical sections of $0.8-0.9 \mu \mathrm{m}$ thick were taken in both xyz and xzy. To prevent interference from the fluorescent probes, images of the same optical section were taken as separate channels, and they were analyzed by using ImageJ software.

\section{Preparation of nuclear extracts}

Briefly, $1.5 \times 10^{6}$ cells were lysed with $0.1 \%$ nonionic detergent Nonidet P40 in Buffer A $(10 \mathrm{mM}$ Tris- $\mathrm{HCl}$, $\mathrm{pH} 7.4,10 \mathrm{mM} \mathrm{NaCl}, 6 \mathrm{mM} \mathrm{MgCl}_{2}, 10 \mathrm{mM} \mathrm{NaF}, 1 \mathrm{mM}$ $\mathrm{Na}_{3} \mathrm{VO}_{4}, 1 \mathrm{mM}$ DTT, $1 \mathrm{mM}$ PMSF). Lysates were pelleted at $636 \boldsymbol{g}$ for $15 \mathrm{~min}$ and resuspended in Buffer B (20 mM HEPES, pH 7.9, $420 \mathrm{mM} \mathrm{NaCl,} \mathrm{20 \%} \mathrm{glycerol}$ $1.5 \mathrm{mM} \mathrm{MgCl}_{2}, 0.2 \mathrm{mM}$ EDTA, $1 \mathrm{mM} \mathrm{Na}_{3} \mathrm{VO}_{4}, 10 \mathrm{mM} \mathrm{NaF}$,

This work is licensed under a Creative Commons Attribution-NonCommercial-NoDerivatives 4.0 enternationad ticense ifica.com at 04/26/2023 11:19:36AM 
A MDA-MB-231

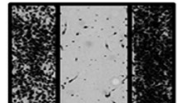

Unstimulated

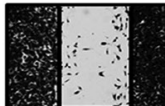

OA /DC260126

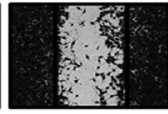

OA

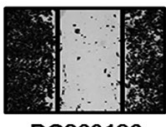

B MDA-MB-231
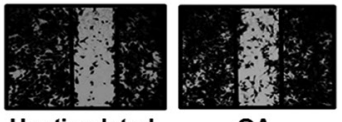

Unstimulated

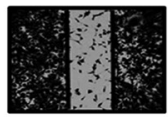

OA I

AH7614

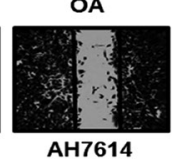

C MDA-MB-231

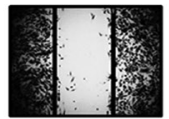

Unstimulated
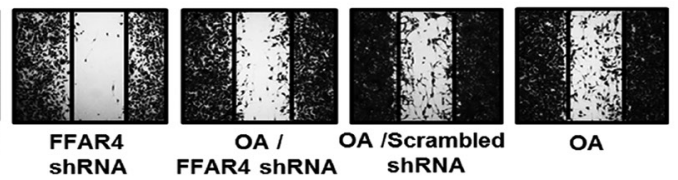

ShRNA

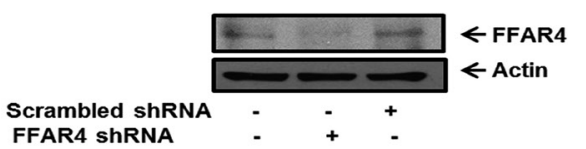

FFAR4 ShRNA

OA

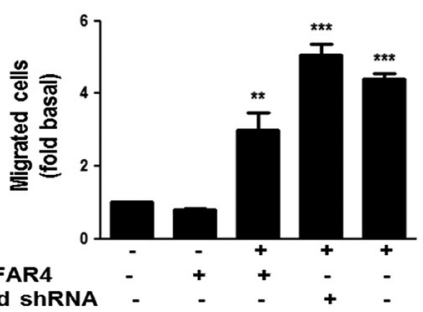

Scrambled shRNA

D MCF-7
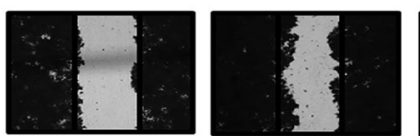

Unstimulated

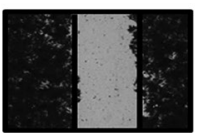

DC260126

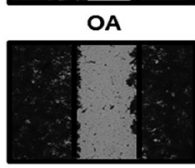

OA/AH7614

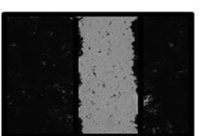

OA/DC260126

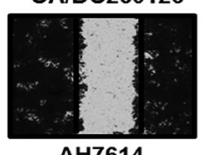

AH7614
DC260126
OA/DC260126

OA/AH7614

AH7614

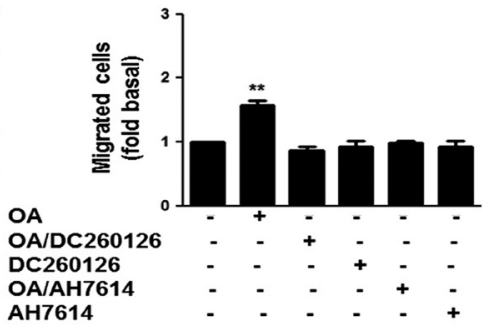

\section{Figure 1}

FFAR1 and FFAR4 mediate migration induced by OA in breast cancer cells. Panel (A), (B) and (D) Cultures of MDA-MB-231 and MCF-7 cells were treated with DC260126 or AH7614, scratchwounded and stimulated with $100 \mu \mathrm{M}$ OA for 48 h. Panel (C) MDA-MB-231 cells were transfected with FFAR4 shRNA or scramble shRNA and cell lysates were analyzed by Western blotting with anti-FFAR4 Ab. Cultures of MDA-MB-231 cells transfected with FFAR4 shRNA or scramble shRNA were scratch-wounded and stimulated with $100 \mu \mathrm{M}$ OA for $48 \mathrm{~h}$. Graphs represent the mean \pm S.D. of at least three independent experiments and are expressed as fold of migrated cells above unstimulated cells. $* * p<0.01, * * * p<0.001$
$1 \mathrm{mM}$ DTT, 0.2 mM PMSF). Nuclear extracts were recovered by centrifugation at $17,136 \boldsymbol{g}$ for $15 \mathrm{~min}$ at $4^{\circ} \mathrm{C}$ and the protein level of each sample was determined by the micro Bradford protein assay.

\section{Electrophoretic mobility shift assay (EMSA)}

Double-stranded oligonucleotide containing specific binding sites for NFkB, 5' AGCTAAGGGACTTTCCGC TGGGGACTTTCCAGG 3', was used as probe. A total amount of $20 \mathrm{pmol}$ of annealed $\mathrm{NF \kappa B}$ oligonucleotide was labeled with $\left(\gamma^{-32} \mathrm{P}\right)$ ATP using T4 polynucleotide kinase. The ${ }^{32}$ P-labeled oligonucleotide probe $(\sim 1 \mathrm{ng})$ was incubated with $5 \mu \mathrm{g}$ of nuclear extract in a reaction mixture containing $3 \mu \mathrm{g}$ of poly (dI-dC), 0.25 M HEPES $\mathrm{pH} 7.5,0.6 \mathrm{M} \mathrm{KCl}, 50 \mathrm{mM} \mathrm{MgCl}, 1 \mathrm{mM}$ EDTA, $7.5 \mathrm{mM}$ DTT and $9 \%$ glycerol for $20 \mathrm{~min}$ at $4^{\circ} \mathrm{C}$. One hundredfold excess of unlabeled $\mathrm{NF \kappa B}$ probe and an irrelevant oligonucleotide were used as specific and nonspecific competitors. The samples were fractionated on a $6 \%$ 


\section{A MDA-MB-231}

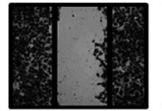

Unstimulated

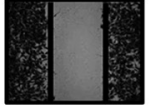

LY294002
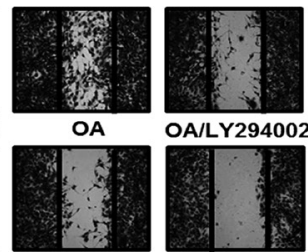

B MCF-7

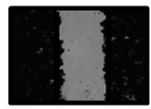

Unstimulated

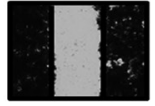

OA/A6730

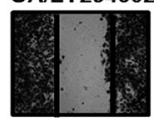

A6730

A6730
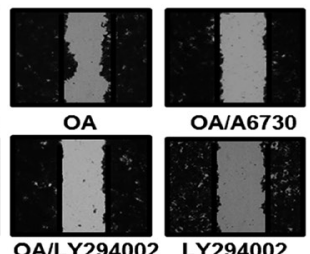

C MDA-MB-231

Akt1-IP

p-Akt BLOT
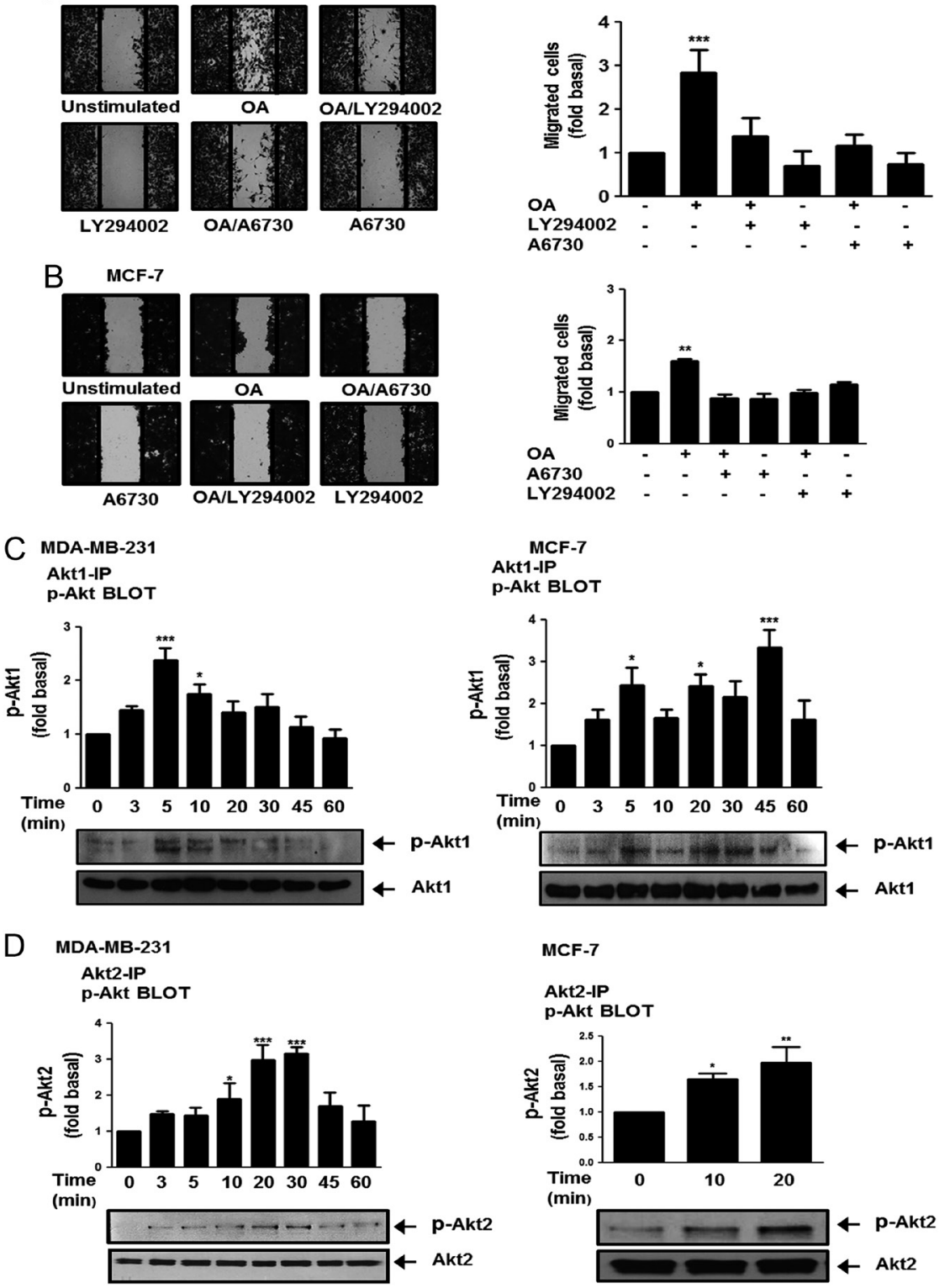

$$
\begin{aligned}
& \text { MCF-7 } \\
& \text { Akt1-IP } \\
& \text { p-Akt BLOT }
\end{aligned}
$$

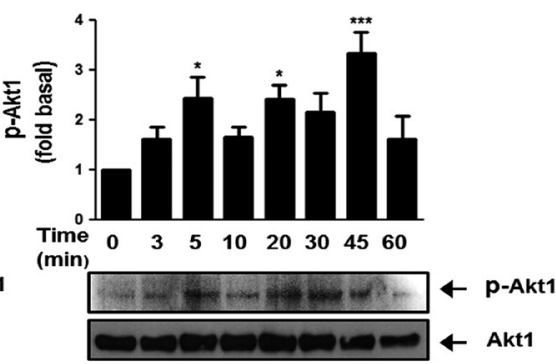

Figure 2

OA induces migration through a PI3K/AKTdependent pathway. Panel (A) and (B) Cultures of MDA-MB-231 and MCF-7 cells were treated with LY294002 or A6730, scratch-wounded and treated with OA. Panel (C) and (D) Lysates from MDA-MB-231 and MCF-7 cells treated with OA for various times were analyzed by immunoprecipitation (IP) with Akt1 Ab or Akt2 Ab followed by Western blotting with anti-p-Akt-Thr $\mathrm{Ab}$ and anti-p-Akt-Ser Ab, respectively. Membranes were analyzed further by Western blotting with anti-Akt1 or Akt2 Ab. Graphs represent the mean \pm S.D. of at least three independent experiments and are expressed as fold of migrated cells or p-Akt- 1 or -2 above unstimulated cells. ${ }^{*} P<0.05, * * p<0.01$ $* * * P<0.001$. polyacrylamide gel in 0.5X Tris borate-EDTA buffer. Gels were dried and analyzed by autoradiography.

\section{Statistical analysis}

Results are expressed as mean \pm s.D. of at least three independent experiments. Data were statistically analyzed using one-way ANOVA and the pairwise comparison was performed using Newman-Keuls multiple comparison test. Control comparison was performed using Dunnett's test. Statistical probability of $P<0.05$ was considered significant.

\section{Results}

FFAR1 and FFAR4 mediate migration induced by OA in breast cancer cells

OA induces migration of MDA-MB-231 breast cancer cells $(8,30)$. We determined the role of FFAR1 and FFAR4 on migration induced by $\mathrm{OA}$ in breast cancer cells. Cultures of MDA-MB-231 and MCF-7 breast cancer cells were treated for $1 \mathrm{~h}$ with $3 \mu \mathrm{M}$ DC260126 or $10 \mu \mathrm{M}$ AH7614, which are selective inhibitors of FFAR1 and FFAR4 respectively $(31,32,33)$, and then they were scratchwounded and stimulated with $100 \mu \mathrm{M}$ OA for $48 \mathrm{~h}$. 
A MDA-MB-231
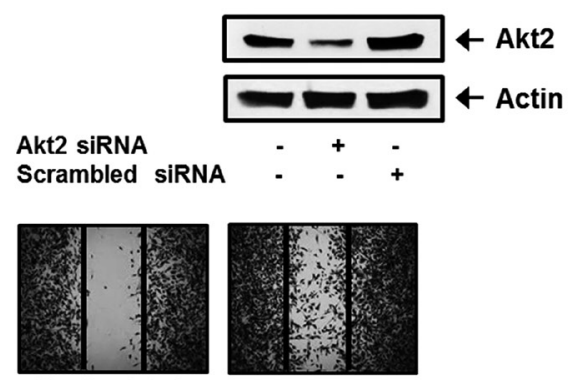

Unstimulated

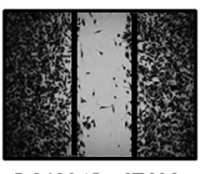

OA

OA/Akt2 siRNA

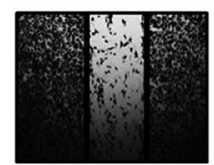

Scrambled

B MCF-7

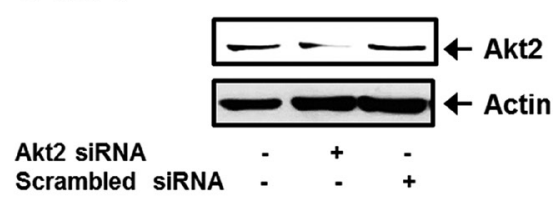

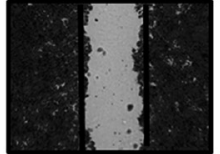

Unstimulated

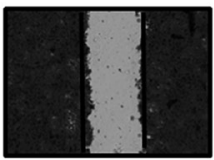

OA/Akt2 siRNA

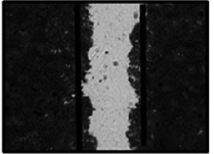

OA

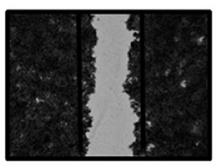

Scrambled

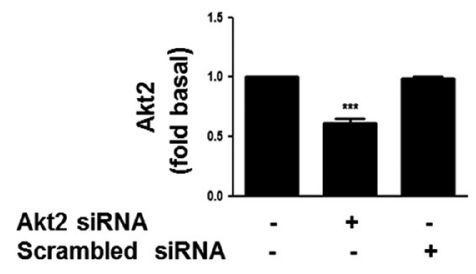

OA

Akt2 siRnA

Scrambled siRNA

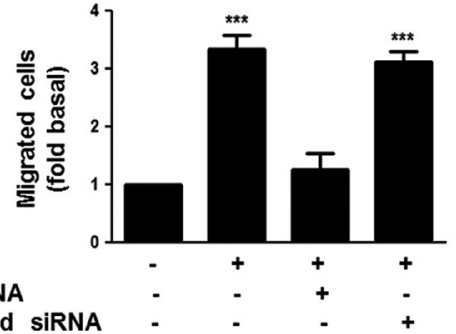

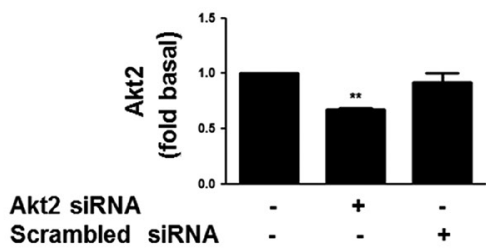

$O A$

Akt2 siRNA

Scrambled SiRNA

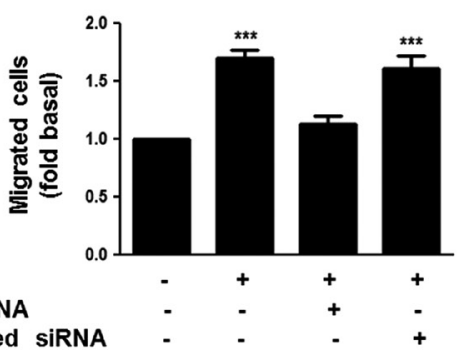

Figure 3

OA induces migration through an AKT2-

dependent pathway. Panel (A) and (B)

MDA-MB-231 and MCF-7 cells were transfected

with Akt2 siRNA or scrambled siRNA and cell

lysates were analyzed by Western blotting with anti-Akt2 Ab. Cultures of MDA-MB-231 and MCF-7 cells transfected with Akt2 siRNA or scrambled siRNA were scratch-wounded and stimulated with OA. Graphs represent the mean \pm s.D. of at least three independent experiments and are expressed as fold of Akt 2 or migrated cells above unstimulated cells. $* * P<0.01 * * * P<0.001$.
As illustrated in Fig. 1A and B, treatment with DC260126 completely inhibited migration, whereas treatment with AH7614 partly inhibited migration induced by OA in MDA-MB-231 cells.

To further substantiate the role of FFAR4 in cell migration of MDA-MB-231 cells. Cultures of MDA-MB-231 cells, in which FFAR4 expression was knocked down by using shRNA against FFAR4, were scratch-wounded and treated with $100 \mu \mathrm{M}$ OA for $48 \mathrm{~h}$. In agreement with our previous results, migration induced by $\mathrm{OA}$ is partly dependent of FFAR4 expression in MDA-MB-231 cells (Fig. 1C).

We also studied the role of FFAR1 and FFAR4 in migration induced by $\mathrm{OA}$ in another breast cancer cell (MCF-7). Our findings showed that treatment with DC260126 and AH7614 completely inhibited migration induced by OA in MCF-7 cells (Fig. 1D).

\section{OA induces migration through a} PI3K/AKT2-dependent pathway

In order to determine the role of PI3K and AKT $1 / 2$ on cell migration, we used selective inhibitors of PI3K and Akt1/2, namely LY294002 and A6730 respectively (34, 35). Cultures of MDA-MB-231 and MCF-7 cells were treated for $1 \mathrm{~h}$ with $10 \mu \mathrm{M}$ LY294002 or $2 \mu \mathrm{M}$ A6730, and then they were scratch-wounded and stimulated with $100 \mu \mathrm{M}$ OA for $48 \mathrm{~h}$. Our results showed that inhibition of PI3K and AKT1/2 activity inhibited migration induced by OA in MDA-MB-231 and MCF-7 cells (Fig. 2A and B).

Since migration induced by $\mathrm{OA}$ required AKT1/2 activity; we determined whether OA induces AKT1/2 activation and the role of AKT2 on cell migration. First, AKT1/2 activation was studied by using the phosphorylation of Akt1 at Thr-308 and phosphorylation

is work is licensed under a Creative Commons Attribution-NonCommercial-NoDerivatives 4.0 Internationad bicense.ifica.com at 04/26/2023 11:19:36Am 
A MDA-MB-231

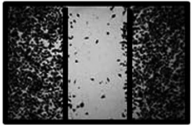

Unstimulated

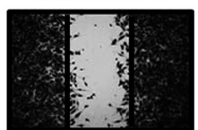

OA /BAI

B MCF-7

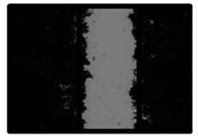

Unstimulated

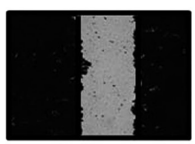

OA/BAI

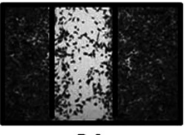

$\mathrm{OA}$

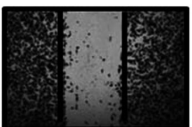

BAI
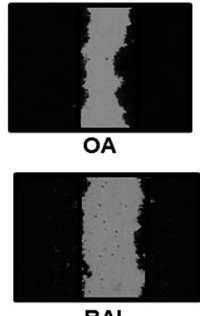

C MDA-MB-231

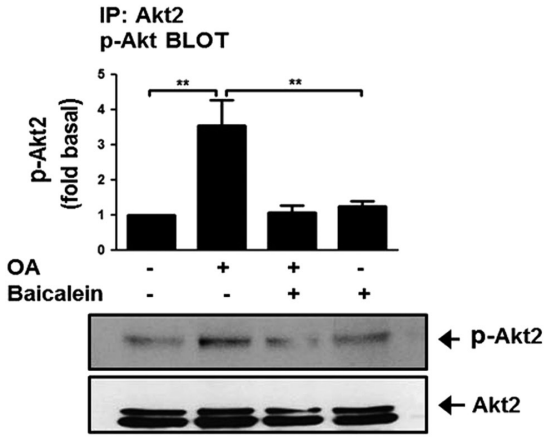

D MDA-MB-231

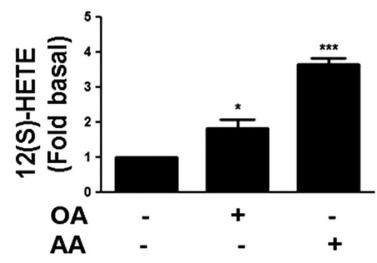

of Akt2 at Ser-474 (22). MDA-MB-231 and MCF-7 cells were stimulated with $100 \mu \mathrm{M}$ OA for various times and lysed. Lysates were analyzed by immunoprecipitation (IP) with anti-Akt1 $\mathrm{Ab}$ or anti-Akt2 $\mathrm{Ab}$, followed by Western blotting with anti-p-Akt-Thr $\mathrm{Ab}$ and anti-p-Akt-Ser $\mathrm{Ab}$, respectively. As illustrated in Fig. 2C and D, OA induced AKT1 and AKT2 phosphorylation at Thr-308/309 and Ser-473/474, respectively, in MDA-MB-231 and MCF-7 cells.

Next, we inhibited Akt2 expression in MDA-MB-231 and MCF-7 cells by using an Akt2 siRNA. Our findings showed a clear inhibition of Akt2 expression. Moreover, cultures of MDA-MB-231 and MCF-7 cells transfected with Akt2 siRNA and scramble siRNA were scratch-wounded and treated with $100 \mu \mathrm{M}$ OA for $48 \mathrm{~h}$. Our results showed that migration induced by $\mathrm{OA}$ required Akt 2 expression in MDA-MB-231 and MCF-7 cells (Fig. 3A and B).

\section{Baicalein inhibits migration and activation of AKT2} and FAK induced by $\mathrm{OA}$

We studied the effect of baicalein in migration induced by OA in MDA-MB-231 and MCF-7 cells, because it is an inhibitor of $12-\mathrm{LOX}$ and $15-\mathrm{LOX}(36,37)$. Migration assays were performed by using MDA-MB-231 and MCF-7 cells treated with $20 \mu \mathrm{M}$ baicalein for $24 \mathrm{~h}$ and stimulated with $100 \mu \mathrm{M} \mathrm{OA}$ for $48 \mathrm{~h}$. Our results showed that treatment with baicalein inhibited migration induced by $\mathrm{OA}$ in MDA-MB-231 and MCF-7 cells (Fig. 4A and B).
Baicalein inhibits migration and activation of AKT2 and FAK induced by $O A$. Panel (A) and (B) Cultures with baicalein (BAI), scratch-wounded and treated treated with $\mathrm{BAl}$ and stimulated with $\mathrm{OA}$ were alyzed by IP with Akt2 Ab or FAK Ab, followed $\mathrm{p}$-FAK Ab. Membranes were analyzed further by Western blotting with anti-Akt2 or FAK Ab. Panel ELISA in supernatants from MDA-MB-231 cells reated with OA or AA. Graphs represent the experiments and are expressed as fold of migrated cells, p-Akt2, p-FAK or 12(S)-HETE above unstimulated cells. $* P<0.05, * * P<0.01$ $* * * P<0.001$ 
A MDA-MB-231
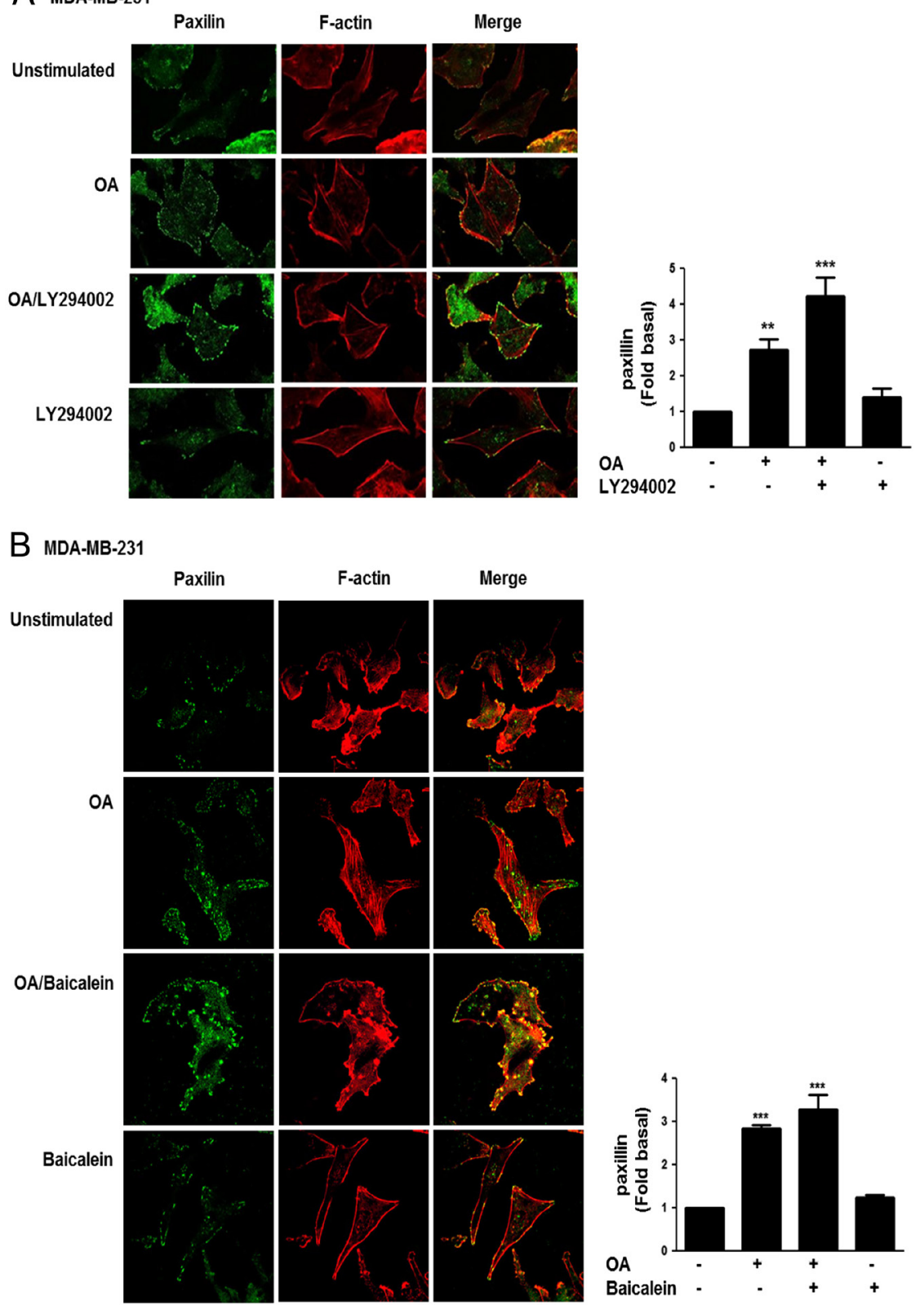

\section{Figure 5}

Focal contacts formation induced by $\mathrm{OA}$ requires PI3K activity. MDA-MB-231 cells cultured on coverslips were treated with LY294002 (Panel A) or baicalein (Panel B) and stimulated with OA. Cells were fixed and focal contacts were analyzed by staining with anti-paxillin $\mathrm{Ab}$ conjugated to FITC. F-actin was stained with TRITC-conjugated phalloidin. F-actin structures are shown in red, and focal adhesions are shown in green. Graphs represent the mean \pm S.D. of at least three independent experiments and are expressed as mean fluorescent intensities of paxillin above unstimulated cells. $* * P<0.01, * * * P<0.001$.

Next, we studied the effect of baicalein in FAK and AKT2 activation. MDA-MB-231 cells were treated with $20 \mu \mathrm{M}$ baicalein for $24 \mathrm{~h}$ and stimulated with $100 \mu \mathrm{M}$ OA for $10 \mathrm{~min}$ (FAK) and $20 \mathrm{~min}$ (Akt2). AKT2 and FAK activation were analyzed by IP with anti-Akt2 Ab and anti-FAK Ab followed of Western blotting with anti-pAkt-Thr Ab and anti-p-FAK Ab. As illustrated in Fig. 4C and $\mathrm{D}$, treatment with baicalein inhibited AKT2 and FAK activation induced by OA in MDA-MB-231 cells.

We also determined whether OA induced 12(S)-HETE secretion. Conditioned medium from MDA-MB-231 cells treated with $100 \mu \mathrm{M}$ OA for $15 \mathrm{~min}$ was analyzed to determine the concentration of 12(S)-HETE. Our findings demonstrated that $\mathrm{OA}$ induced the secretion of 12(S)-HETE in MDA-MB-231 cells (Fig. 4E). One control of 12(S)-HETE secretion was included (AA).

\section{Focal contacts formation induced by $O A$ requires PI3K activity}

We studied whether $\mathrm{OA}$ induced focal contacts formation and the effect of a PI3K inhibitor and baicalein. MDA-MB-231 cells were cultured on coverslips and treated for $1 \mathrm{~h}$ with $10 \mu \mathrm{M}$ LY294002 or $20 \mu \mathrm{M}$ baicalein 
A MDA-MB-231
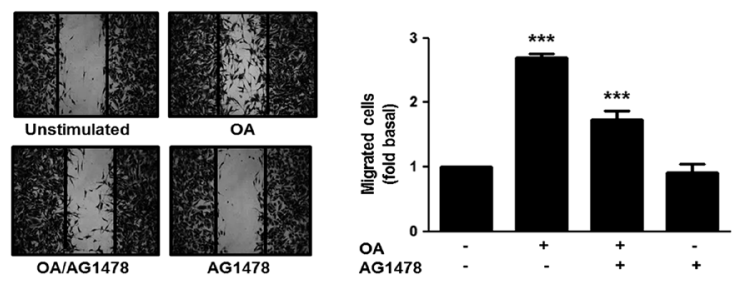

B mcF-7
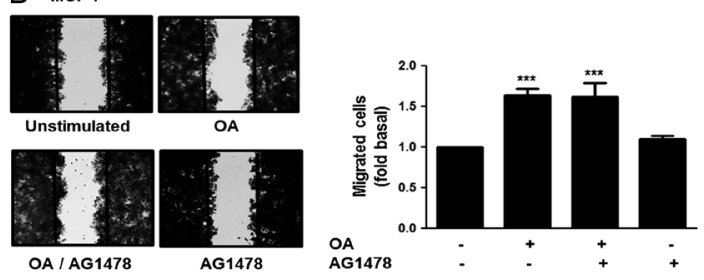

C MDA-MB-231
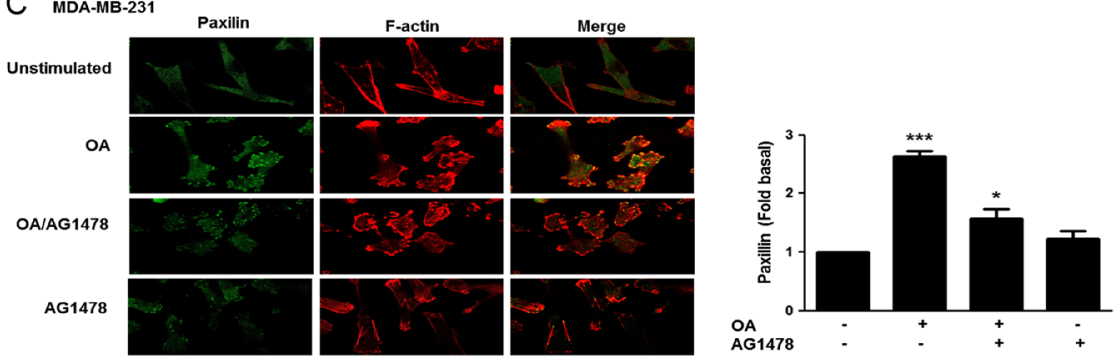

\section{Figure 6}

Role of EGFR in migration and focal contacts formation induced by OA. Panel (A) and (B) Cultures of MDA-MB-231 and MCF-7 cells were treated with AG1478, scratch-wounded and treated with OA. Panel (C) MDA-MB-231 cells cultured on coverslips were treated with AG1478 and stimulated with OA. Cells were fixed and focal contacts were analyzed by staining with anti-paxillin Ab conjugated to FITC. F-actin was stained with TRITC-conjugated phalloidin. F-actin structures are shown in red, and focal adhesions are shown in green. Graphs represent the mean \pm S.D. of at least three independent experiments and are expressed as fold of migrated cells or mean fluorescent intensities of paxillin above unstimulated cells. $* P<0.05$, $* * * p<0.001$.

for $24 \mathrm{~h}$, and then cells were stimulated with $100 \mu \mathrm{M}$ OA for $15 \mathrm{~min}$. The presence of focal contacts was analyzed by immunofluorescence analysis of paxillin, because it is a protein localized in focal contacts (38). Our findings showed that $\mathrm{OA}$ induced an increase in the number of focal contacts in MDA-MB-231 cells. Interestingly, treatment with a PI3K inhibitor and baicalein increased the number and size of focal contacts induced by $\mathrm{OA}$ in MDA-MB-231 cells (Fig. 5A and B).

\section{Role of EGFR on migration and focal contacts formation induced by $O A$}

We studied the role of EGFR on cell migration and focal contacts formation. Migration assays were performed by using MDA-MB-231 and MCF-7 cells treated for $30 \mathrm{~min}$ with 500 nM AG1478, a selective inhibitor of EGFR (39), and stimulated with $100 \mu \mathrm{M}$ OA for $48 \mathrm{~h}$. As illustrated in Fig. 6A, treatment with AG1478 partly inhibited the migration induced by $\mathrm{OA}$ in MDA-MB-231 cells. In contrast, treatment with AG1478 did not inhibit migration induced by OA in MCF-7 cells (Fig. 6B). In addition, treatment with AG1478 inhibited the increased number and size of focal contacts induced by OA in MDA-MB-231 cells (Fig. 6C).

\section{OA induces invasion and NFKB-DNA binding activity}

Since, OA induces invasion in MDA-MB-231 cells (10), we studied the role of PI3K and AKT1/2 in the invasion process. Invasion assays were performed by using the Boyden chamber method and MDA-MB-231 cells treated for $1 \mathrm{~h}$ with $10 \mu \mathrm{M}$ LY294002 or $2 \mu \mathrm{M}$ A6730 and stimulated with $100 \mu \mathrm{M}$ OA for $48 \mathrm{~h}$. Our findings demonstrated that invasion induced by $\mathrm{OA}$ in MDA-MB-231 cells is dependent on PI3K and AKT1/2 activity (Fig. 7A).

The NFkB transcription factor mediates expression of genes implicated in invasion process. We determined whether OA induced an increase of NFкB-DNA binding activity in MDA-MB-231 cells. Nuclear extracts from MDA-MB-231 cells stimulated with $100 \mu \mathrm{M}$ OA for various times were analyzed by EMSA using a radiolabeled probe representing a canonical NFkB binding site. Our findings demonstrated that OA induced an increase of NFkB-DNA binding activity at 45 min of stimulation in MDA-MB-231 cells (Fig. 7B). Next, we studied whether OA also induced an increase of NFkB-DNA binding activity in MCF-7 cells and the role of PI3K and AKT1/2. MCF-7 and MDA-MB-231 cells were treated with $10 \mu \mathrm{M}$ LY294002 or $2 \mu \mathrm{M}$ A6730 and stimulated with $100 \mu \mathrm{M}$ OA for $45 \mathrm{~min}$, nuclear extracts were obtained and analyzed by EMSA. As illustrated in https://ec.bioscientifica.com https://doi.org/10.1530/EC-18-0543 (c) 2019 The authors Published by Bioscientifica Ltd
This work is licensed under a Creative Commons Attribution-NonCommercial-NoDerivatives 4.0 Internationab sicense.ifica . com at 04/26/2023 11:19:36 AM 
A MDA-MB-231

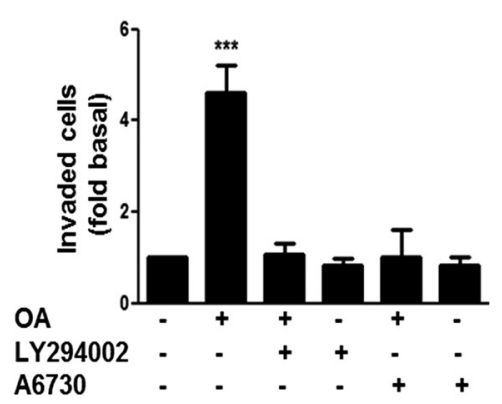

B MDA-MB-231

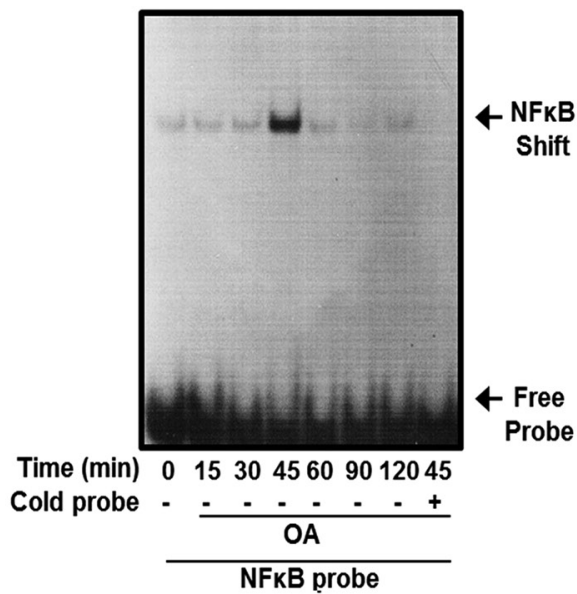

C MCF-7

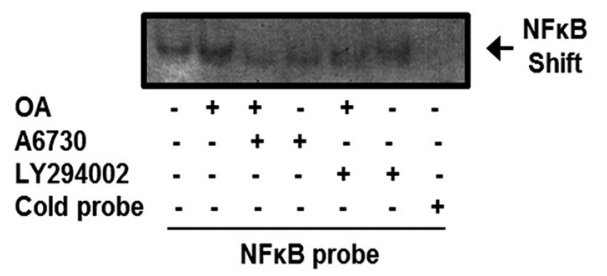

MDA-MB-231

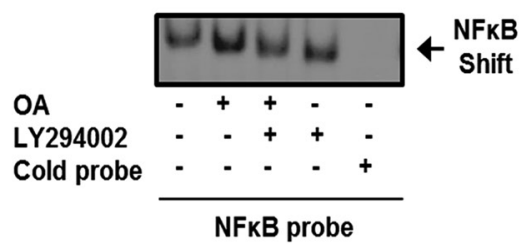

E MDA-MB-231

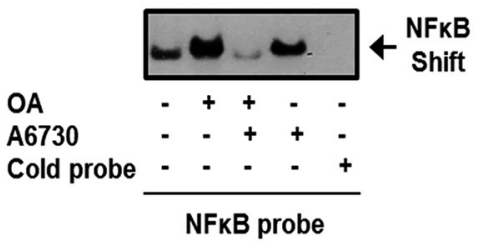

\section{Figure 7}

OA induces invasion and NFkB-DNA binding activity. Panel (A) Invasion assays were performed by using the Boyden chamber method and MDA-MB-231 cells treated with LY294002 or A6730 and stimulated with OA. Graph represents the mean \pm s.D. of three independent experiments and is expressed as fold of invasion above unstimulated cells. Panel (B) MDA-MB-231 cells were treated with $\mathrm{OA}$ for various times and nuclear extracts were obtained. Panel (C, D and E) MCF-7 and MDA-MB-231 cells were treated with LY294002 or A6730, stimulated with OA and nuclear extracts were obtained. NFkB-DNA binding activity was analyzed by EMSA. Control included EMSA reactions with 100-fold excess of cold NFkB competitor (Cold probe). Results shown are representative of three independent experiments. ${ }^{* *} P<0.001$.
Fig. 7C, D and E, OA induced an increase of NFкB binding activity through a PI3K- and AKT1/2-dependent pathway in MCF-7 and MDA-MB-231 cells.

\section{Discussion}

Epidemiological studies in women strongly suggest that obesity and dietary factors including a high intake of fat and meat enhance the risk of breast cancer $(4,40,41)$. We previously demonstrated that $\mathrm{OA}$ induces proliferation, invasion, MMP-9 secretion, activation of ERK1/2, FAK and Src, and an increase of AP1-DNA binding activity in breast cancer cells $(8,9,10)$. However, the signal transduction pathways involved in migration and invasion induced by OA in breast cancer cells remains to be studied.

FFAR1 and FFAR4 have been involved in cancer progression (42). Particularly, OA induces an increase of intracellular $\mathrm{Ca}^{2+}$ levels via FFAR1 in MCF-7 breast cancer cells, whereas it promotes proliferation through a
FFAR1-dependent pathway in MDA-MB-231 breast cancer cells $(6,43)$. We demonstrate here that OA induces migration through a FFAR1- and FFAR4-dependent pathway in MCF-7 cells. However, OA induces migration through a FFAR1dependent pathway and it is partly dependent on FFAR4 activity in MDA-MB-231 cells. In contrast to our findings, $n-3$ fatty acids inhibit proliferation via FFAR 1 and FFAR4 in MDA-MB-231 and MCF-7 cells (44). Moreover, inhibition of FFAR1 expression promotes migration but loss of FFAR4 expression inhibits migration in pancreatic cancer cells PANC-1 (45). In addition, FFAR1 is a negative regulator of migration and invasion in HT1080 fibrosarcoma cells (46). We propose that natural ligands of FFARs, including OA, mediate specific responses in breast cancer cells through activation of FFAR1 and/or FFAR4. Therefore, the role of FFARs in the cell responses mediated by different free fatty acids should be studied in different cell types.

Mouse models and cell cultures suggest that AKT family members do not have redundant functions, because 


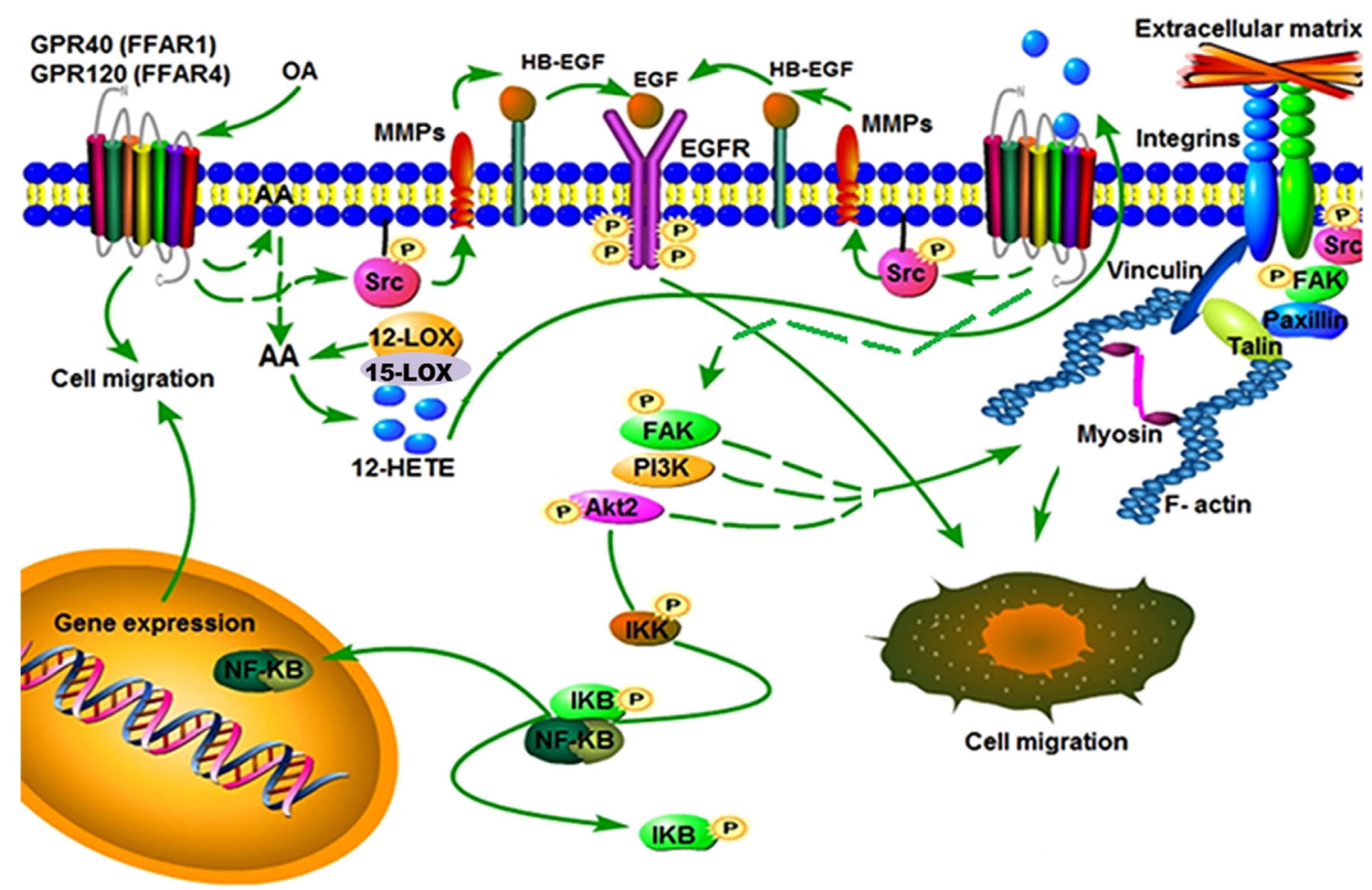

Figure 8

Model of signal transduction pathways that mediate migration induced by OA in breast cancer cells.

each AKT member fulfills unique functions in normal and tumor cells $(47,48)$. Particularly, AKT1 activation promotes tumorigenesis and suppresses invasion in a mouse model of mammary tumorigenesis induced by ErbB-2 expression; whereas overexpression of Akt2 induces upregulation of integrin $\beta 1$ and an increase of invasion and metastasis in breast and ovarian cancer cells $(49,50)$. We demonstrate here that $\mathrm{OA}$ induces migration through a PI3K- and AKT-dependent pathway in MDA-MB-231 and MCF-7 cells. In addition, OA induces invasion via PI3K and AKT activity, whereas migration requires AKT2 activity in MDA-MB-231 cells. Since, OA induces activation of AKT1 and AKT2 in MDA-MB-231 and MCF-7 cells, it remains to be investigated, the role of AKT1 in migration and the role of AKT1 in the invasion process. We propose that OA induces FFAR1/FFAR4 activation, and then activation of PI3K/AKT pathway, which mediate migration and invasion in breast cancer cells. Supporting our proposal, an agonist of FFAR4 (TUG891) induces phosphorylation of AKT at Ser-473 (51).

Cell adhesion is the attachment among cells and surrounding environment, including extracellular matrix (ECM). Cellular motility is an essential process that mediates metastasis and involves the adhesion and detachment of ECM. Moreover, adhesion induces activation of signal transduction pathways that mediate proliferation and survival $(52,53)$. Focal contacts are structures wherein integrin receptors mediate interaction between actin cytoskeleton and ECM, which are composed of diverse cell components including scaffolding proteins, adaptor proteins, GTPases, kinases and phosphatases $(54,55)$.

We demonstrate here that stimulation of MDA-MB-231 cells with $\mathrm{OA}$ induces formation of focal contacts and treatment with a PI3K inhibitor and OA increased the number and size of focal contacts and inhibition of migration. We propose that PI3K/AKT activation induced by OA mediates the disassembly of focal contacts during migration in MDA-MB-231 cells. In agreement with our findings, migration of MCF-7 cells requires Rac1dependent actin organization through activation of PI3K, whereas, migration and invasion are regulated by Rho-A/PI3K activity in BLM melanoma cells $(56,57,58)$.

LOXs pathway is composed of a dioxygenases family including 5-, 12- and 15-LOX-1/-2, and their main products are 5(S)-, 12(S)- and 15(S)-HETE, respectively (26). Particularly, 12-LOX is expressed in a variety of tumors, including breast cancer, whereas, 12(S)-HETE has been involved in the invasion and metastasis of tumor cells $(59,60)$. We propose that 12 -LOX and/or 15-LOX mediate migration and focal contact formation

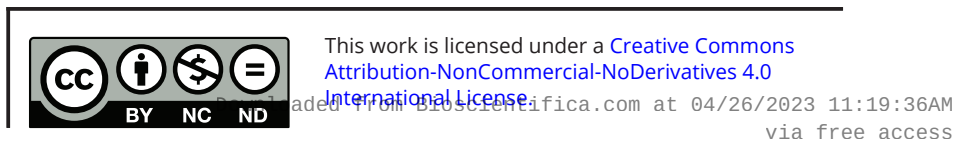


through AKT2 and FAK activation in MDA-MB-231 and MCF-7 cells. Supporting our proposal, we demonstrate here that OA induces secretion of 12(S)-HETE in MDA-MB-231 cells, whereas 12-LOX activates PI3K/AKT and MMP-9 expression through NFкB in prostate cancer cells PC-3 (61)

Transactivation of EGFR induced by GPCRs occurs via MMPs activation and release of EGF-like ligands (HB-EGF) from precursors in the plasmatic membrane (62). We previously demonstrated that $\mathrm{OA}$ induces ERK1/2 activation, an increase of AP-1 DNA binding activity and invasion through an EGFR transactivationdependent pathway in breast cancer cells $(9,10)$. We demonstrate here that $\mathrm{OA}$ induces migration through EGFR in MDA-MB-231 and MCF-7 cells, whereas it partly mediates focal contacts formation in MDA-MB-231 cells. We propose that OA induces EGFR transactivation and then activated EGFR mediates AKT activation, migration and gene expression in breast cancer cells. Supporting our proposal, migration and proliferation of non-small cell lung cancer cells require EGFR activity and phosphoERK, whereas knockdown of glucose transporter decreases proliferation, migration and invasion via modulation of EGFR/MAPK signaling pathway in MDA-MB-231 cells $(63,64)$.

The transcription factor NFKB has been associated broadly with the development and progression of several cancers, because it mediates expression of genes implicated in angiogenesis and metastasis, including TNF, IL-1, iNOS, MMP-9 and urokinase-type plasminogen activator (uPA) $(65,66)$. In PTEN-null/inactive prostate cancer cells, AKT mediates NFkB activity via interaction and stimulation of IKK, whereas a model of prostate cancer progression in TRAMP mice show a differential protein expression of PI3K, AKT phosphorylated at Ser-473, IKK kinase activity and NFkB DNA binding activity $(67,68)$. We demonstrate here that OA induces an increase of NFKB-DNA binding activity and it requires the activity of PI3K and AKT in MDA-MB-231 and MCF-7 cells. We propose that $\mathrm{OA}$ induces $\mathrm{NFKB}$ activation and expression of genes implicated in migration and invasion in breast cancer cells.

In conclusion, our findings demonstrate FFAR1/ FFAR4, AKT, PI3K, EGFR and NFKB activation play a pivotal role in the migration and invasion processes in breast cancer cells (Fig. 8).

\section{Declaration of interest}

The authors declare that there is no conflict of interest that could be perceived as prejudicing the impartiality of the research reported.

\section{Funding}

This work was supported by a grant from CONACYT-Mexico (255429). C M-M and C G-R are supported by a CONACYT predoctoral training grant.

\section{Author contribution statement}

C M-M and E P S designed and analyzed the experiments, and wrote the manuscript. C M-M and P C-R performed the experiments. C G-R participated in critical revision of manuscript.

\section{Acknowledgements}

We are grateful to Nora Ruiz for her technical assistance.

\section{References}

1 Rossini A, Zanobbio L, Sfondrini L, Cavalleri A, Secreto G, Morelli D Palazzo M, Sommariva M, Tagliabue E, Rumio C, et al. Influence of fatty acid-free diet on mammary tumor development and growth rate in HER-2/Neu transgenic mice. Journal of Cellular Physiology 2013 228 242-249. (https://doi.org/10.1002/jcp.24130)

2 Carmichael AR. Obesity and prognosis of breast cancer. Obesity Reviews 20067 333-340. (https://doi.org/10.1111/j.1467-789X.2006.00261.x)

3 Xue F \& Michels KB. Diabetes, metabolic syndrome, and breast cancer: a review of the current evidence. American Journal of Clinical Nutrition 200786 s823-s835. (https://doi.org/10.1093/ ajcn/86.3.823S)

4 Calle EE \& Kaaks R. Overweight, obesity and cancer: epidemiological evidence and proposed mechanisms. Nature Reviews Cancer 20044 579-591. (https://doi.org/10.1038/nrc1408)

5 Byon CH, Hardy RW, Ren C, Ponnazhagan S, Welch DR, McDonald JM \& Chen Y. Free fatty acids enhance breast cancer cell migration through plasminogen activator inhibitor-1 and SMAD4. Laboratory Investigation 200989 1221-1228. (https://doi.org/10.1038/ labinvest.2009.97)

6 Hardy S, St-Onge GG, Joly E, Langelier Y \& Prentki M. Oleate promotes the proliferation of breast cancer cells via the $\mathrm{G}$ proteincoupled receptor GPR40. Journal of Biological Chemistry 2005280 13285-13291. (https://doi.org/10.1074/jbc.M410922200)

7 McArthur MJ, Atshaves BP, Frolov A, Foxworth WD, Kier AB \& Schroeder F. Cellular uptake and intracellular trafficking of long chain fatty acids. Journal of Lipid Research 199940 1371-1383.

8 Navarro-Tito N, Soto-Guzman A, Castro-Sanchez L, MartinezOrozco R \& Salazar EP. Oleic acid promotes migration on MDA-MB-231 breast cancer cells through an arachidonic acid-dependent pathway. International Journal of Biochemistry and Cell Biology 201042 306-317. (https://doi.org/10.1016/j. biocel.2009.11.010)

9 Soto-Guzman A, Robledo T, Lopez-Perez M \& Salazar EP. Oleic acid induces ERK1/2 activation and AP-1 DNA binding activity through a mechanism involving Src kinase and EGFR transactivation in breast cancer cells. Molecular and Cellular Endocrinology 2008294 81-91. (https://doi.org/10.1016/j.mce.2008.08.003)

10 Soto-Guzman A, Navarro-Tito N, Castro-Sanchez L, MartinezOrozco R \& Salazar EP. Oleic acid promotes MMP-9 secretion and invasion in breast cancer cells. Clinical and Experimental Metastasis 201027 505-515. (https://doi.org/10.1007/s10585-010-9340-1)

11 Hirasawa A, Tsumaya K, Awaji T, Katsuma S, Adachi T, Yamada M, Sugimoto Y, Miyazaki S \& Tsujimoto G. Free fatty acids regulate gut incretin glucagon-like peptide-1 secretion through GPR120. Nature Medicine 200511 90-94. (https://doi.org/10.1038/nm1168)

12 Briscoe CP, Tadayyon M, Andrews JL, Benson WG, Chambers JK Eilert MM, Ellis C, Elshourbagy NA, Goetz AS, Minnick DT, et al. 
The orphan G protein-coupled receptor GPR40 is activated by medium and long chain fatty acids. Journal of Biological Chemistry 2003278 11303-11311. (https://doi.org/10.1074/jbc.M211495200)

13 Briscoe CP, Peat AJ, McKeown SC, Corbett DF, Goetz AS, Littleton TR, McCoy DC, Kenakin TP, Andrews JL, Ammala C, et al. Pharmacological regulation of insulin secretion in min6 cells through the fatty acid receptor GPR40: identification of agonist and antagonist small molecules. British Journal of Pharmacology 2006148 619-628. (https://doi.org/10.1038/sj.bjp.0706770)

14 Cartoni C, Yasumatsu K, Ohkuri T, Shigemura N, Yoshida R, Godinot N, le Coutre J, Ninomiya Y \& Damak S. Taste preference for fatty acids is mediated by GPR40 and GPR120. Journal of Neuroscience 201030 8376-8382. (https://doi.org/10.1523/ JNEUROSCI.0496-10.2010)

15 Ozdener MH, Subramaniam S, Sundaresan S, Sery O, Hashimoto T, Asakawa Y, Besnard P, Abumrad NA \& Khan NA. CD36- and GPR120mediated $\mathrm{Ca}(2)(+)$ signaling in human taste bud cells mediates differential responses to fatty acids and is altered in obese mice. Gastroenterology 2014146 995-1005. (https://doi.org/10.1053/j. gastro.2014.01.006)

16 Oh DY, Walenta E, Akiyama TE, Lagakos WS, Lackey D, Pessentheiner AR, Sasik R, Hah N, Chi TJ, Cox JM, et al. A Gpr120-selective agonist improves insulin resistance and chronic inflammation in obese mice. Nature Medicine 201420 942-947. (https://doi.org/10.1038/nm.3614)

17 Navarro-Tito N, Robledo T \& Salazar EP. Arachidonic acid promotes FAK activation and migration in MDA-MB-231 breast cancer cells. Experimental Cell Research 2008314 3340-3355. (https://doi. org/10.1016/j.yexcr.2008.08.018)

18 Engelman JA, Luo J \& Cantley LC. The evolution of phosphatidylinositol 3-kinases as regulators of growth and metabolism. Nature Reviews Genetics 20067 606-619. (https://doi. org/10.1038/nrg1879)

19 Engelman JA. Targeting PI3K signalling in cancer: opportunities, challenges and limitations. Nature Reviews Cancer 20099 550-562. (https://doi.org/10.1038/nrc2664)

20 Fresno Vara JA, Casado E, de Castro J, Cejas P, Belda-Iniesta C \& Gonzalez-Baron M. PI3K/Akt signalling pathway and cancer. Cancer Treatment Reviews 200430 193-204. (https://doi.org/10.1016/j. ctrv.2003.07.007)

21 Dillon RL, White DE \& Muller WJ. The phosphatidyl inositol 3-kinase signaling network: implications for human breast cancer. Oncogene 200726 1338-1345. (https://doi.org/10.1038/ sj.onc.1210202)

22 Dillon RL \& Muller WJ. Distinct biological roles for the Akt family in mammary tumor progression. Cancer Research 201070 4260-4264. (https://doi.org/10.1158/0008-5472.CAN-10-0266)

23 Irie HY, Pearline RV, Grueneberg D, Hsia M, Ravichandran P, Kothari N, Natesan S \& Brugge JS. Distinct roles of Akt1 and Akt2 in regulating cell migration and epithelial-mesenchymal transition. Journal of Cell Biology 2005171 1023-1034. (https://doi.org/10.1083/ jcb.200505087)

24 Maloberti P, Cornejo Maciel F, Castillo AF, Castilla R, Duarte A, Toledo MF, Meuli F, Mele P, Paz C \& Podesta EJ. Enzymes involved in arachidonic acid release in adrenal and Leydig cells. Molecular and Cellular Endocrinology 2007 265-266 113-120. (https://doi. org/10.1016/j.mce.2006.12.026)

25 Dessen A. Structure and mechanism of human cytosolic phospholipase A(2). Biochimica and Biophysica Acta 20001488 40-47. (https://doi.org/10.1016/S1388-1981(00)00108-6)

26 Brash AR. Lipoxygenases: occurrence, functions, catalysis, and acquisition of substrate. Journal of Biological Chemistry $1999 \mathbf{2 7 4}$ 23679-23682. (https://doi.org/10.1074/jbc.274.34.23679)

27 Urade Y, Watanabe K \& Hayaishi O. Prostaglandin D, E, and F synthases. Journal of Lipid Mediators and Cell Signalling 199512 257-273. (https://doi.org/10.1016/0929-7855(95)00032-L)
28 Harizi H, Corcuff JB \& Gualde N. Arachidonic-acid-derived eicosanoids: roles in biology and immunopathology. Trends in Molecular Medicine 200814 461-469. (https://doi.org/10.1016/j. molmed.2008.08.005)

29 Soto-Guzman A, Villegas-Comonfort S, Cortes-Reynosa P \& Perez Salazar E. Role of arachidonic acid metabolism in Stat5 activation induced by oleic acid in MDA-MB-231 breast cancer cells. Prostaglandins, Leukotrienes, and Essential Fatty Acids $2013 \mathbf{8 8}$ 243-249. (https://doi.org/10.1016/j.plefa.2012.12.003)

30 Li S, Zhou T, Li C, Dai Z, Che D, Yao Y, Li L, Ma J, Yang X \& Gao G. High metastaticgastric and breast cancer cells consume oleic acid in an AMPK dependent manner. PLoS One 20149 e97330. (https://doi. org/10.1371/journal.pone.0097330)

31 Sparks SM, Chen G, Collins JL, Danger D, Dock ST, Jayawickreme C, Jenkinson S, Laudeman C, Leesnitzer MA, Liang X, et al. Identification of diarylsulfonamides as agonists of the free fatty acid receptor 4 (FFA4/GPR120). Bioorganic and Medicinal Chemistry Letters 201424 3100-3103. (https://doi.org/10.1016/j.bmcl.2014.05.012)

32 Sun P, Wang T, Zhou Y, Liu H, Jiang H, Zhu W \& Wang H. DC260126: a small-molecule antagonist of GPR40 that protects against pancreatic beta-Cells dysfunction in $\mathrm{db} / \mathrm{db}$ mice. PLoS One $2013 \mathbf{8}$ e66744. (https://doi.org/10.1371/journal.pone.0066744)

33 Hu H, He LY, Gong Z, Li N, Lu YN, Zhai QW, Liu H, Jiang HL, Zhu WL \& Wang HY. A novel class of antagonists for the FFAs receptor GPR40. Biochemical and Biophysical Research Communications 2009390 557-563. (https://doi.org/10.1016/j.bbrc.2009.10.004)

$34 \mathrm{Hu}$ C, Huang L, Gest C, Xi X, Janin A, Soria C, Li H \& Lu H. Opposite regulation by PI3K/Akt and MAPK/ERK pathways of tissue factor expression, cell-associated procoagulant activity and invasiveness in MDA-MB-231 cells. Journal of Hematology and Oncology 2012516 (https://doi.org/10.1186/1756-8722-5-16)

35 Vlahos CJ, Matter WF, Hui KY \& Brown RF. A specific inhibitor of phosphatidylinositol 3-kinase, 2-(4-morpholinyl)-8-phenyl-4H-1benzopyran-4-one (LY294002). Journal of Biological Chemistry 1994 269 5241-5248.

36 Xu J, Zhang Y, Xiao Y, Ma S, Liu Q, Dang S, Jin M, Shi Y, Wan B \& Zhang Y. Inhibition of 12/15-lipoxygenase by baicalein induces microglia PPARbeta/delta: a potential therapeutic role for CNS autoimmune disease. Cell Death and Disease 20134 e569. (https:// doi.org/10.1038/cddis.2013.86)

37 Deschamps JD, Kenyon VA \& Holman TR. Baicalein is a potent in vitro inhibitor against both reticulocyte 15-human and platelet 12-human lipoxygenases. Bioorganic and Medicinal Chemistry 200614 4295-4301. (https://doi.org/10.1016/j.bmc.2006.01.057)

38 Schaller MD. Paxillin: a focal adhesion-associated adaptor protein. Oncogene 200120 6459-6472. (https://doi.org/10.1038/ sj.onc.1204786)

39 Ward WH, Cook PN, Slater AM, Davies DH, Holdgate GA \& Green LR. Epidermal growth factor receptor tyrosine kinase. Investigation of catalytic mechanism, structure-based searching and discovery of a potent inhibitor. Biochemical Pharmacology 199448 659-666. (https://doi.org/10.1016/0006-2952(94)90042-6)

40 Boyd NF, Stone J, Vogt KN, Connelly BS, Martin LJ \& Minkin S. Dietary fat and breast cancer risk revisited: a meta-analysis of the published literature. British Journal of Cancer 200389 1672-1685. (https://doi.org/10.1038/sj.bjc.6601314)

41 Lahmann PH, Hoffmann K, Allen N, van Gils CH, Khaw KT, Tehard B, Berrino F, Tjonneland A, Bigaard J, Olsen A, et al. Body size and breast cancer risk: findings from the European Prospective Investigation into Cancer and Nutrition (EPIC). International Journal of Cancer 2004111 762-771. (https://doi.org/10.1002/ijc.20315)

42 Houthuijzen JM. For better or worse: FFAR1 and FFAR4 signaling in cancer and diabetes. Molecular Pharmacology 201690 738-743. (https://doi.org/10.1124/mol.116.105932)

43 Yonezawa T, Katoh K \& Obara Y. Existence of GPR40 functioning in a human breast cancer cell line, MCF-7. Biochemical and 
Biophysical Research Communications 2004314 805-809. (https://doi. org/10.1016/j.bbrc.2003.12.175)

44 Hopkins MM, Zhang Z, Liu Z \& Meier KE. Eicosopentaneoic acid and other free fatty acid receptor agonists inhibit lysophosphatidic acid- and epidermal growth factor-induced proliferation of human breast cancer cells. Journal of Clinical Medicine 20165 16. (https://doi. org/10.3390/jcm5020016)

45 Fukushima K, Yamasaki E, Ishii S, Tomimatsu A, Takahashi K, Hirane M, Fukushima N, Honoki K \& Tsujiuchi T. Different roles of GPR120 and GPR40 in the acquisition of malignant properties in pancreatic cancer cells. Biochemical and Biophysical Research Communications 2015465 512-515. (https://doi.org/10.1016/j. bbrc.2015.08.050)

46 Ishii S, Kitamura Y, Hirane M, Tomimatsu A, Fukushima K, Takahashi K, Fukushima N, Honoki K \& Tsujiuchi T. Negative effects of G-protein-coupled free fatty acid receptor GPR40 on cell migration and invasion in fibrosarcoma HT1080 cells. Molecular Carcinogenesis 201655 1553-1559. (https://doi.org/10.1002/mc.22408)

47 Clark AR \& Toker A. Signalling specificity in the Akt pathway in breast cancer. Biochemical Society Transactions 201442 1349-1355. (https://doi.org/10.1042/BST20140160)

48 Chin YR \& Toker A. Akt isoform-specific signaling in breast cancer: uncovering an anti-migratory role for palladin. Cell Adhesion and Migration 2011 5 211-214. (https://doi.org/10.4161/cam.5.3.15790)

49 Hutchinson JN, Jin J, Cardiff RD, Woodgett JR \& Muller WJ. Activation of Akt-1 (PKB-alpha) can accelerate ErbB-2-mediated mammary tumorigenesis but suppresses tumor invasion. Cancer Research 200464 3171-3178. (https://doi.org/10.1158/0008-5472. CAN-03-3465)

50 Arboleda MJ, Lyons JF, Kabbinavar FF, Bray MR, Snow BE, Ayala R, Danino M, Karlan BY \& Slamon DJ. Overexpression of AKT2/protein kinase Bbeta leads to up-regulation of beta1 integrins, increased invasion, and metastasis of human breast and ovarian cancer cells. Cancer Research 200363 196-206.

51 Prihandoko R, Alvarez-Curto E, Hudson BD, Butcher AJ, Ulven T, Miller AM, Tobin AB \& Milligan G. Distinct phosphorylation clusters determine the signaling outcome of free fatty acid receptor $4 / \mathrm{G}$ protein-coupled Receptor 120. Molecular Pharmacology 201689 505-520. (https://doi.org/10.1124/mol.115.101949)

52 Wells A, Grahovac J, Wheeler S, Ma B \& Lauffenburger D. Targeting tumor cell motility as a strategy against invasion and metastasis. Trends in Pharmacological Sciences 201334 283-289. (https://doi. org/10.1016/j.tips.2013.03.001)

53 Alizadeh AM, Shiri S \& Farsinejad S. Metastasis review: from bench to bedside. Tumour Biology 201435 8483-8523. (https://doi. org/10.1007/s13277-014-2421-z)

54 Guo W \& Giancotti FG. Integrin signalling during tumour progression. Nature Reviews. Molecular Cell Biology 20045 816-826. (https://doi.org/10.1038/nrm1490)

55 Wozniak MA, Modzelewska K, Kwong L \& Keely PJ. Focal adhesion regulation of cell behavior. Biochimica and Biophysica Acta 20041692 103-119. (https://doi.org/10.1016/j.bbamcr.2004.04.007)
56 Kallergi G, Agelaki S, Markomanolaki H, Georgoulias V \& Stournaras C. Activation of FAK/PI3K/Rac1 signaling controls actin reorganization and inhibits cell motility in human cancer cells. Cellular Physiology and Biochemistry 200720 977-986. (https://doi org/10.1159/000110458)

57 Monterrubio M, Mellado M, Carrera AC \& Rodriguez-Frade JM. PI3Kgamma activation by CXCL12 regulates tumor cell adhesion and invasion. Biochemical and Biophysical Research Communications 2009 388 199-204. (https://doi.org/10.1016/j.bbrc.2009.07.153)

58 Reiske HR, Kao SC, Cary LA, Guan JL, Lai JF \& Chen HC. Requirement of phosphatidylinositol 3-kinase in focal adhesion kinase-promoted cell migration. Journal of Biological Chemistry 1999 274 12361-12366. (https://doi.org/10.1074/jbc.274.18.12361)

59 Honn KV, Tang DG, Gao X, Butovich IA, Liu B, Timar J \& Hagmann W. 12-lipoxygenases and 12(S)-HETE: role in cancer metastasis. Cancer Metastasis Reviews 199413 365-396. (https://doi. org/10.1007/BF00666105)

60 Mashima R \& Okuyama T. The role of lipoxygenases in pathophysiology; new insights and future perspectives. Redox Biology 20156 297-310. (https://doi.org/10.1016/j.redox.2015.08.006)

61 Dilly AK, Ekambaram P, Guo Y, Cai Y, Tucker SC, Fridman R, Kandouz M \& Honn KV. Platelet-type 12-lipoxygenase induces MMP9 expression and cellular invasion via activation of PI3K/Akt/ NF-kappaB. International Journal of Cancer 2013133 1784-1791. (https://doi.org/10.1002/ijc.28165)

62 Fischer OM, Hart S, Gschwind A \& Ullrich A. EGFR signal transactivation in cancer cells. Biochemical Society Transactions 2003 31 1203-1208. (https://doi.org/10.1042/)

63 Oh S, Kim H, Nam K \& Shin I. Glut1 promotes cell proliferation, migration and invasion by regulating epidermal growth factor receptor and integrin signaling in triple-negative breast cance cells. BMB Reports 201750 132-137. (https://doi.org/10.5483/ BMBRep.2017.50.3.189)

64 Han T, Guo M, Zhang T, Gan M, Xie C \& Wang JB. A novel glutaminase inhibitor-968 inhibits the migration and proliferation of non-small cell lung cancer cells by targeting EGFR/ERK signaling pathway. Oncotarget 20178 28063-28073. (https://doi.org/10.18632/ oncotarget.14188)

65 Prasad S, Ravindran J \& Aggarwal BB. NF-kappaB and cancer: how intimate is this relationship. Molecular and Cellular Biochemistry 2010 336 25-37. (https://doi.org/10.1007/s11010-009-0267-2)

66 Karin M. Nuclear factor-kappaB in cancer development and progression. Nature $2006 \mathbf{4 4 1}$ 431-436. (https://doi.org/10.1038/ nature04870)

67 Shukla S, Maclennan GT, Marengo SR, Resnick MI \& Gupta S. Constitutive activation of P I3 K-Akt and NF-kappaB during prostate cancer progression in autochthonous transgenic mouse model. Prostate 200564 224-239. (https://doi.org/10.1002/pros.20217)

68 Dan HC, Cooper MJ, Cogswell PC, Duncan JA, Ting JP \& Baldwin AS. Akt-dependent regulation of NF-\{kappa\}B is controlled by mTOR and Raptor in association with IKK. Genes and Development 200822 1490-1500. (https://doi.org/10.1101/gad.1662308)

Received in final form 29 January 2019

Accepted 4 February 2019

Accepted Preprint published online 5 February 2019 https://ec.bioscientifica.com https://doi.org/10.1530/EC-18-0543 (c) 2019 The authors Published by Bioscientifica Ltd
This work is licensed under a Creative Commons Attribution-NonCommercial-NoDerivatives 4.0 Internationab ticense. fica com at $04 / 26 / 2023$ 11:19:36AM 